\title{
Changes in Pain and Nutritional Intake Modulate Ultra-Running Performance: A Case Report
}

\author{
Russ Best ${ }^{1,2,3, *}$, Benjamin Barwick ${ }^{3}$, Alice Best ${ }^{3}$, Nicolas Berger ${ }^{1,2}$, Claire Harrison ${ }^{4}$, \\ Matthew Wright ${ }^{5}\left({ }^{-1}\right.$ and Julie Sparrow ${ }^{2,3}$ \\ 1 Centre for Sport Science \& Human Performance, Waikato Institute of Technology, \\ Hamilton 3288, New Zealand; N.Berger@tees.ac.uk \\ 2 School of Health and Social Care, Teesside University, Middlesbrough TS3 1BX, UK; J.Sparrow@tees.ac.uk \\ 3 Full Potential Performance Ltd., Plymouth PL4 0RA, UK; ben@fullpotential.co.uk; alicebackhurst@me.com \\ 4 Freelance Dietician, Newcastle upon Tyne NE1, UK claire@c-harrison.co.uk \\ 5 Teesside Sport, Teesside University, Middlesbrough TS3 1BX, UK; M.Wright@tees.ac.uk \\ * Correspondence: Russell.Best@wintec.ac.nz; Tel.: +64-021-129-7900
}

Received: 29 August 2018; Accepted: 28 September 2018; Published: 4 October 2018

\begin{abstract}
Ultra-endurance running provides numerous physiological, psychological, and nutritional challenges to the athlete and supporting practitioners. We describe the changes in physiological status, psychological condition, and nutritional intake over the course of two 100-mile running races, with differing outcomes: non-completion and completion. Athlete perception of pain, freshness, and motivation differed between events, independent of rating of perceived exertion. Our data suggest that the integration of multiple sensations (freshness, motivation, hunger, pain, and thirst) produce performance. Increases in carbohydrate feeding $\left(+5 \mathrm{~g} \cdot \mathrm{h}{ }^{-1}\right)$ and protein intake $\left(+0.3 \mathrm{~g} \cdot \mathrm{kg}^{-1}\right)$ also likely contributed to successful completion of a 100-mile race, by reducing the fractional utilization of maximal oxygen uptake and satiating hunger, respectively. Nutritional data support the notion that the gut is a trainable, and critical organ with respect to ultra-endurance performance. Finally, we propose future research to investigate the rate at which peak feeding occurs throughout ultra-endurance events, as this may further serve to personalize sports nutrition strategies.
\end{abstract}

Keywords: ultra-endurance; running; nutrition

\section{Introduction}

Ultra-running is considered to be any running event in excess of a standard marathon (42.2 km [1]). Participation in these events has increased in recent years, on a domestic (Great Britain) and European scale, independent of age or gender [2]. Races are staged in either single-day or multi-day formats, with the latter offering the opportunity for overnight recovery between race segments. Other events have standardised race distances $(50 \mathrm{~km}, 50$ miles, $100 \mathrm{~km}$, and 100 miles [1]), or time periods (6 h, $24 \mathrm{~h}$, and multi-day events [1]). Differing terrain and environmental conditions, including extreme temperatures or high altitude, affect the difficulty of such events.

Throughout ultra-marathons interactions between psychological and physiological factors can influence performance [3], yet currently these are poorly understood [3]. These interactions may hold a key to better understanding what limits performance in this group of athletes [4], especially in amateur participants [3,5]. Athletes' rating of perceived exertion (RPE) may oscillate during an event in accordance with fluctuations in other characteristics, such as pacing, pain [4,6], mental fatigue [7], and maximal sustainable power [5]. It is unlikely that these factors act in isolation with respect to performance. More likely, an athlete's psychological state interacts with their physiological condition, and the environmental conditions, with all fluctuating throughout the race $[8,9]$. 
Many physiological variables affect ultra-marathon running performance, most notably the energetic cost of running (running economy) and anthropometric characteristics of an individual [10] with lactate threshold (LT) and maximal oxygen uptake $\left(\mathrm{VO}_{2 \max }\right)$ also being considered physiologically important [11]. In comparison to shorter distances, a lower fractional utilisation of $\mathrm{VO}_{2 \max }$ must be sustained over a much longer duration, although this has been demonstrated to increase throughout a $90 \mathrm{~km}$ ultra-marathon [12], incurring a progressive worsening of the cost of running. Ultra-endurance activity also places significant demands upon the muscular and osteo-articular systems, with substantial changes in bone health [4,13] and bone metabolism [14] being reported. Successful adaptation, and not deterioration of muscular and osteo-articular systems might be a contributing factor to race success [11].

Appropriate nutrition [15-17] and hydration [18,19] strategies may attenuate performance decrements during ultra-endurance running. Meeting energy requirements is challenging $[20,21]$ and achieving adequate carbohydrate $(\mathrm{CHO})$ intake is preferable to maximise overall calorie consumption $[15,20,21]$. A sustained and well-tolerated $\mathrm{CHO}$ intake, preferably from multiple transportable sources [22], has been shown to support prolonged high-intensity activity, with more pronounced effects being observed in longer events [23]. Gastro-intestinal (GI) symptoms during ultra-endurance events are frequently reported; therefore, attenuation of GI symptoms either through nutritional training [24] or physiological adaptation [22] might play a part in successful completion and competitive racing over ultra-distances. Carbohydrate intakes of $71 \pm 20 \mathrm{~g}$ per hour have been reported in elite ultra-marathon runners [17], attaining current recommendations [22].

This case study describes the physiological and psychological determinants of ultra-endurance running performance, over two contrasting attempts (non-completion vs. completion). The inclusion of nutritional data adds to the small body of empirical evidence currently available on this aspect of ultra-endurance performance.

\section{Materials and Methods}

The participant's characteristics are presented in Table 1. The participant had 5.5 years running experience and it had recorded a marathon personal best of 2:56:49 as part of their preparation for the first recorded attempt at an ultra-endurance event (100 miles, non-completion). Mean weekly training volume throughout this period was $60 \mathrm{~km} \cdot \mathrm{week}^{-1}$, and it consisted of a variety of training sessions including long runs, interval training, continuous easy running, and conditioning work as prescribed and monitored by their coach. The participant had one unsuccessful ultra-distance attempt prior to seeking support. In between the attempts that are reported in this article, the participant completed a multi-stage ultra-running event, with a mean running distance of $46 . \mathrm{km} \cdot$ day $^{-1}$ over five days.

Table 1. Participant characteristics.

\begin{tabular}{cc}
\hline Characteristic & Value \\
\hline Age & 41 years \\
Height & $168 \mathrm{~cm}$ \\
Weight & $67.1 \mathrm{~kg}$ \\
Running Experience & 5.5 years \\
Current coaching period & 2 years \\
$10 \mathrm{~km} \mathrm{~PB}^{1}$ & $39: 42$ \\
Half Marathon PB & $1: 26: 10$ \\
Marathon PB $^{2: 56: 49}$ \\
Ultra-Marathon Experience $^{2}$ & Previous DNC \\
\hline${ }^{1}$ PB: Personal Best.
\end{tabular}

Ethical approval was obtained from the Teesside University ethics committee, with written informed consent from the participant, in accordance with the Declaration of Helsinki. Data were 
collected at the start and finish of each event, and at official checkpoints throughout. A researcher walked outwards from each checkpoint to meet the participant, and record subjective measures as the participant walked in to the checkpoint where the physiological measures were taken. Finally, the participant's nutritional intake would be recorded, and beverages, foodstuffs, or sports nutrition products would be afforded to the participant before continuing with the race(s). Data collection took $\sim 90$ s per checkpoint during non-completion, and $\sim 60$ s per checkpoint during completion.

Blood glucose and blood lactate values were obtained through finger prick blood sampling, and recorded using portable analysers (Wireless Smart-Gluco Monitoring System, iHealth Labs, Mountain View, CA, USA; Lactate Pro, Cycle Classic Imports, Adelaide, Australia, respectively). All of the blood samples and sampling equipment were disposed of safely, and subsequently incinerated following analysis. The participant's bodyweight $(\mathrm{kg})$ was recorded at each checkpoint while using portable scales (Seca 803 , Seca, Birmingham, UK), and change in bodyweight $(\Delta \mathrm{BW})$ calculated as the difference between the current and previous checkpoints' values. Hydration status was self-reported via subjective urine colour score, using a previously validated eight-point scale [25]. In the incidence of no urine output, a score of 0 was noted.

Blood glucose and lactate sampling were not included for the second attempt (completion). Data for both measures were consistent throughout the course of the unsuccessful attempt, with little range in values being obtained. RPE was thought to be a sufficient reflection of exercise intensity and provision of a similar feeding strategy would elicit similar post-prandial blood glucose values. The exclusion of these measures from the battery also sped up data collection by $\sim 30$ s per checkpoint, thereby reducing time deficits incurred because of data collection.

Visual analogue scales (VAS; $100 \mathrm{~mm}$ ) were used to record feelings of freshness, motivation, hunger, thirst, and pain. Freshness was defined as 'readiness to continue', motivation as 'willingness to continue' and pain as 'an unpleasant sensory and emotional experience associated with actual or potential tissue damage' [26]. Hunger and thirst are homeostatic processes, and therefore were not defined. Each scale represented a continuum from the worst possible outcome, to the best possible outcome, for each sensation. The participant was provided with an example scale on each data collection sheet (one sheet per crewed checkpoint) to ensure accurate and consistent interpretation of the VAS. The participant placed a vertical line at a point along the scale for each characteristic, at each crewed checkpoint, to represent their feeling of each sensation. These data were used to inform nutrition recommendations that were made during the event. Rating of perceived exertion (RPE) was recorded while using a 10-point scale (CR-10; [27]).

Nutritional intake was recorded using a semi-quantitative approach. The number of sports nutrition products consumed by the athlete between checkpoints was tallied, and then the athlete was questioned about other foodstuffs and beverages that they had consumed at non-crewed aid stations. These items were either freely chosen from un-crewed checkpoints manned by race support staff, or given to the athlete directly by the crew. Intakes of foods, liquids, and sports nutrition products were collated and analysed using specialist software (Nutritics Ltd. Co., Dublin, Ireland). Absolute (g) and relative $\left(\mathrm{g} \cdot \mathrm{kg}^{-1}\right)$ carbohydrate and protein consumption were calculated, with total energy intake (kcal) also being reported and principal carbohydrate sources presented separately (glucose, fructose, and sucrose).

Raw data were inputted into Microsoft Excel (Microsoft Corporation, Redmond Washington, WA, USA) for analysis. Pearson's correlations were calculated to assess the association between subjective measures that were reported on the $100 \mathrm{~mm}$ VAS scale across each race. The uncertainty in these data were reported via $90 \%$ confidence intervals and the magnitude of the correlation coefficient was attributed to qualitative descriptors [28]. The following correlation coefficients and descriptors were used: 0.0-0.1 Trivial; 0.1-0.3 Small; 0.3-0.5 Moderate; 0.5-0.7 Large; 0.7-0.9 Very Large; and, 0.9-0.1 Near Perfect.

We assessed the trends across each race using a customised spread sheet for the analysis of individuals, considering both the value that represented the minimal important difference and the 
typical error of the measure [29]. We derived the slope and its standard error and apply these data to understand the likelihood of the athlete experience a substantial decline in subjective wellbeing or increase in RPE at 10, 20, 40,60, and 80 miles. We were also able to estimate the point at which the athlete was "likely" to demonstrate this substantial decline in each race, as well as any "likely" substantial changes between check points. Here, likely was defined as a $75 \%$ chance of a substantial negative change [28]. Between race differences were analysed using a separate customised spreadsheet [30]. The uncertainty in the data was reported via $90 \%$ confidence intervals and qualitative inferences were applied as per recommendations [28,31].

A typical error for our RPE data was taken from previous literature in endurance athletes using the CR-10 scale, 0.69 arbitrary units [32], and the minimal important change was set at 1 arbitrary unit as this can equate to an important difference between verbal anchors e.g., moderate to somewhat hard. We identified that the minimal important change in VAS data as $12 \mathrm{~mm}$ and applied this to all measures of freshness, motivation, hunger, thirst, and pain. This is the mean change that is associated with a patient feeling their pain is "a little bit worse" [33]. A typical error of $9 \mathrm{~mm}$ was chosen for VAS scale measures [34].

\section{Results}

\subsection{Physiological and Subjective Measures}

The linear trends for all subjective data are presented in Figure 1 and include the slope and standard error. Pearson's correlations are presented in Table 2. Differences between changes in VAS score were trivial for RPE and thirst, but substantial differences were observed between races in all other subjective measures. Given large to near perfect correlations between pain and freshness and motivation, we chose only to provide detail between race differences for pain only. Therefore, in Tables 3 and 4, we present a detailed evaluation of the athletes' perceptions of pain and hunger.

\subsection{Nutritional Intake}

Throughout non-completion, the participant consumed a total of $355.3 \mathrm{~g} \mathrm{CHO}$, at a rate of $20.15 \mathrm{~g} \cdot \mathrm{h}^{-1}$. This equated to a relative consumption of $5.3 \mathrm{~g} \cdot \mathrm{CHO} \cdot \mathrm{kg}^{-1}$. Food frequency data shows the majority of this intake came from real foods and beverages as opposed to specialist sports nutrition products $(n=8)$. Over the course of the completion the participant consumed $592.7 \mathrm{~g} \mathrm{CHO}$, at a rate of $25.7 \mathrm{~g} \cdot \mathrm{h}^{-1}$ $\left(8.8 \mathrm{~g} . \mathrm{CHO} \cdot \mathrm{kg}^{-1}\right)$. Fewer sports nutrition products were also consumed throughout the successful attempt $(n=7)$. Absolute protein intake was $90.1 \mathrm{~g}$ and $104 \mathrm{~g}$, resulting in relative intakes of $1.3 \mathrm{~g} \cdot \mathrm{kg}^{-1}$ and $1.6 \mathrm{~g} \cdot \mathrm{kg}^{-1}$ for non-completion and completion, respectively. A total intake of $3776 \mathrm{kcal}$ was recorded in completion with $59 \%$ or $2246 \mathrm{kcal}$ coming from $\mathrm{CHO}$ sources. In contrast $48 \%$ or $1347 \mathrm{kcal}$ were obtained from $\mathrm{CHO}$ sources during non-completion, with fewer calories being consumed overall (2806 kcal). Principal carbohydrate values were all higher (Glucose $42 \mathrm{~g}$, Fructose $52 \mathrm{~g}$ and Sucrose, $98 \mathrm{~g}$ ) in completion than in non-completion (Glucose 27.3; Fructose 32.2; and, Sucrose $75 \mathrm{~g}$ ).

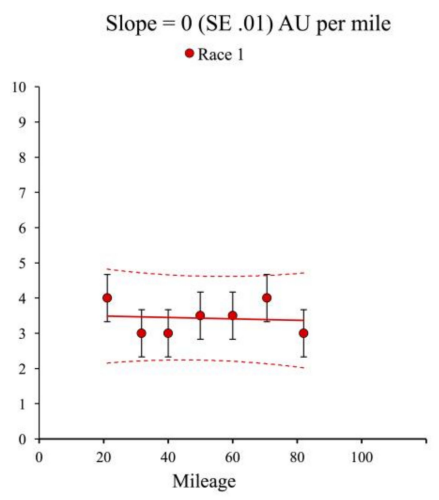

(a)

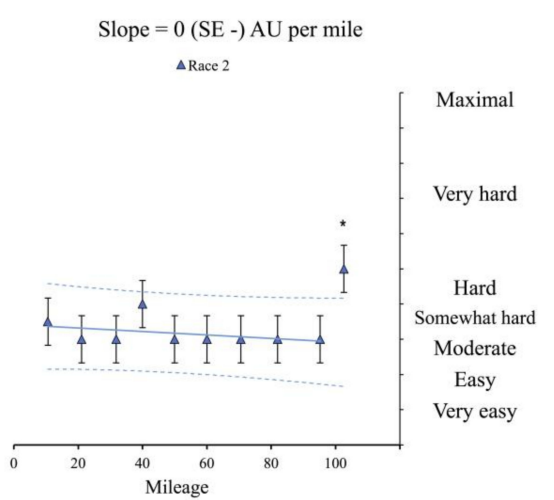

(b)

Figure 1. Cont. 


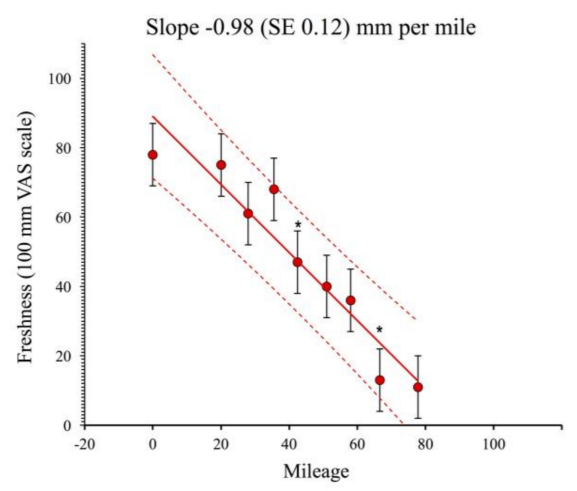

(c)

Slope -1.1 (SE 0.12) mm per mile

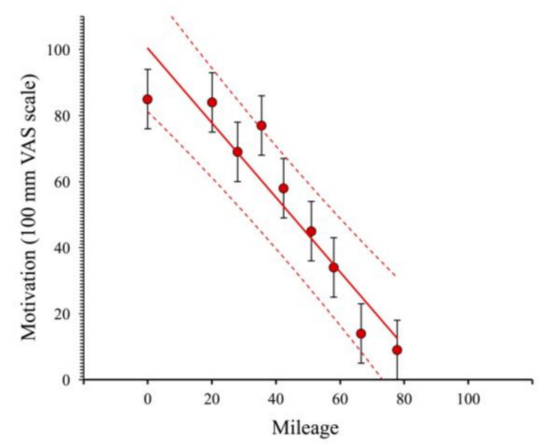

(e)

Slope 0.24 (SE 0.13) mm per mile

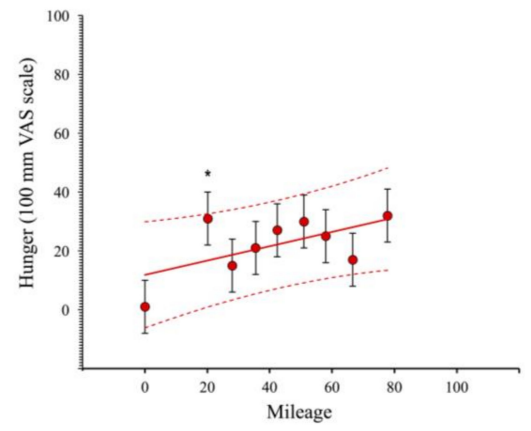

(g)
Slope -0.45 (SE 0.11) mm per mile
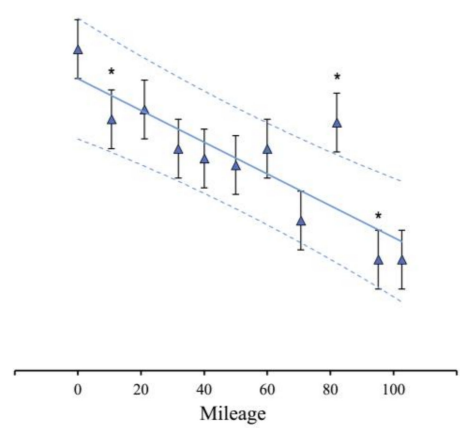

(d)

Slope -0.28 (SE 0.11) mm per mile
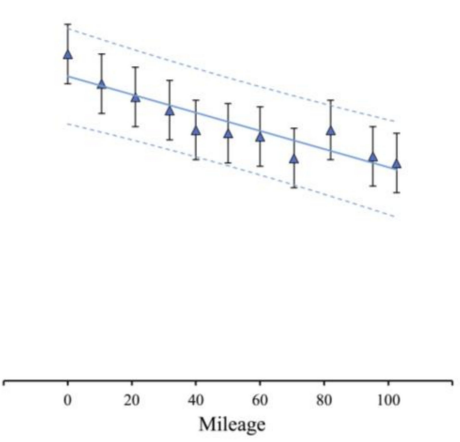

(f)

Slope -0.01 (SE 0.13) mm per mile

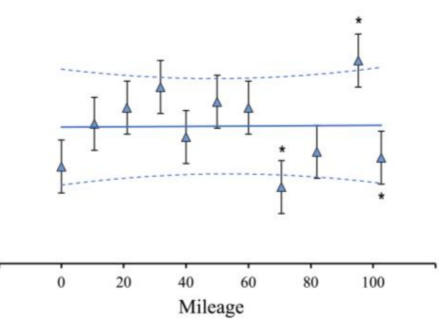

(h)

Figure 1. Cont. 


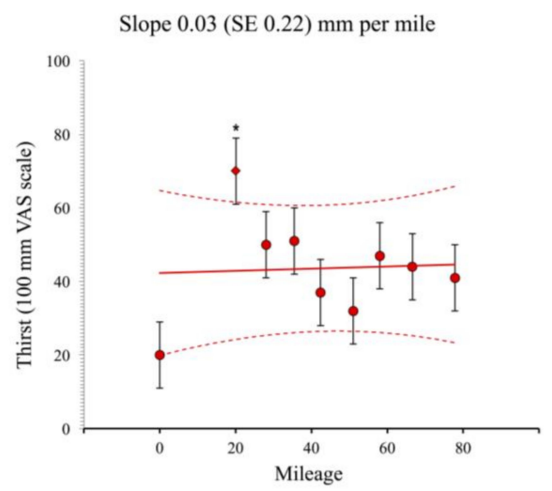

(i)

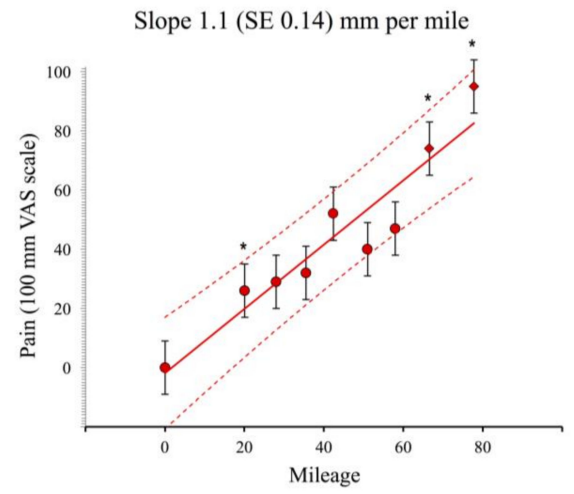

(k)
Slope -0.21 (SE 0.14) mm per mile

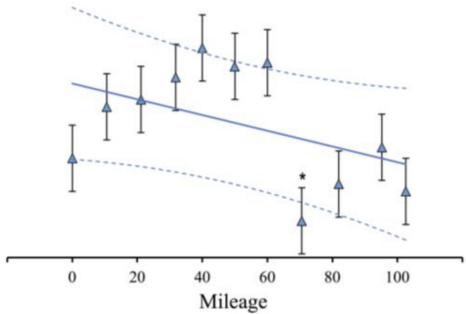

(j)

Slope -0.21 (SE 0.10) mm per mile

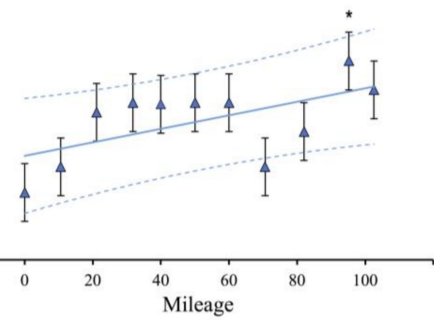

(l)

Figure 1. Panels represent the individual data points for race 1 (red circles) and race 2 (blue triangles). Bars represent the typical error of measurement and values falling outside the dashed lines are estimated to be likely (> 75\% chance) substantially off the trend [29]. Asterisks $\left({ }^{*}\right)$ represent data points that are estimated to be likely different from the previous check point. Panels(a) and (b) depict RPE trends between events; (c) and (d) freshness; (e) and (f) motivation; (g) and (h) hunger; (i) and (j) thirst; and (k) and (1) pain.

Table 2. Pearson's correlations, $90 \%$ confidence intervals and qualitative descriptors for VAS measures. DNC: did not complete.

\begin{tabular}{|c|c|c|c|c|c|}
\hline RACE 1 (DNC) & Freshness & Motivation & Hunger & Thirst & Pain \\
\hline Freshness & 1.00 & $\begin{array}{c}\text { Near Perfect } \\
(0.99,0.96 \text { to } 1.0)\end{array}$ & $\begin{array}{c}\text { Moderate } \\
(0.40,-0.24 \text { to } 0.80)\end{array}$ & $\begin{array}{c}\text { Small } \\
(0.14,-0.49 \text { to } 0.67)\end{array}$ & $\begin{array}{c}\text { Near perfect } \\
(0.93,0.76 \text { to } 0.98)\end{array}$ \\
\hline Motivation & - & 1.00 & $\begin{array}{c}\text { Moderate } \\
(0.38,-0.26 \text { to } 0.79)\end{array}$ & $\begin{array}{c}\text { Small } \\
(0.14,-0.49 \text { to } 0.67)\end{array}$ & $\begin{array}{c}\text { Near perfect } \\
(0.91,0.69 \text { to } 0.98)\end{array}$ \\
\hline Hunger & - & - & 1.00 & $\begin{array}{c}\text { Small } \\
(0.48,-1.5 \text { to } 0.83)\end{array}$ & $\begin{array}{c}\text { Large } \\
(0.56,-0.04 \text { to } 0.86)\end{array}$ \\
\hline Thirst & - & - & - & 1.00 & $\begin{array}{c}\text { Trivial } \\
(0.08,-0.53 \text { to } 0.64)\end{array}$ \\
\hline Pain & - & - & - & - & 1.00 \\
\hline RACE 2 & Freshness & Motivation & Hunger & Thirst & Pain \\
\hline Freshness & 1.00 & $\begin{array}{c}\text { Near Perfect } \\
(0.90,0.74 \text { to } 0.97)\end{array}$ & $\begin{array}{c}\text { Trivial } \\
(0.15,-0.38 \text { to } 0.6)\end{array}$ & $\begin{array}{c}\text { Moderate } \\
(0.31,-0.22 \text { to } 0.7)\end{array}$ & $\begin{array}{c}\text { Large } \\
(0.62,0.17 \text { to } 0.85)\end{array}$ \\
\hline Motivation & - & 1.00 & $\begin{array}{c}\text { Trivial } \\
(0.06,-0.45 \text { to } 0.54)\end{array}$ & $\begin{array}{c}\text { Small } \\
(0.24,-0.29 \text { to } 0.66)\end{array}$ & $\begin{array}{c}\text { Large } \\
(0.63,0.19 \text { to } 0.86)\end{array}$ \\
\hline
\end{tabular}

Table 2. Cont.

\begin{tabular}{cccccc}
\hline RACE 1 (DNC) & Freshness & Motivation & Hunger & Thirst & Pain \\
\hline Hunger & - & - & 1.00 & Large & Very large \\
Thirst & - & - & - & $(0.6,0.14$ to 0.85$)$ & $(0.7,0.3$ to 0.89$)$ \\
Pain & - & - & - & 1.00 & Moderate \\
& & & & - & $(0.33,-0.2$ to 0.71$)$ \\
\end{tabular}


Table 3. Increases in perceived pain over each ultra-marathon run including the likelihood that the athlete was experiences a substantial increase in pain. Likelihoods are presented with the qualitative inference and percentage chance that the increase was substantial or trivial. Differences between are presented as raw change and $90 \%$ confidence interval, with the qualitative inference.

\begin{tabular}{|c|c|c|c|c|c|}
\hline $\begin{array}{l}\text { Miles } \\
\text { (x) }\end{array}$ & $\begin{array}{l}\text { Increases in Perceived } \\
\text { Pain per } x \text { Miles } \\
(\mathrm{mm}, 90 \% \mathrm{CI})\end{array}$ & $\begin{array}{l}\text { Was the Athlete } \\
\text { Experiencing a } \\
\text { Substantial Increase } \\
\text { in Pain? }\end{array}$ & $\begin{array}{l}\text { Increases in Perceived } \\
\text { Pain per } x \text { Miles } \\
(\mathrm{mm}, 90 \% \mathrm{CI})\end{array}$ & $\begin{array}{l}\text { Was the Athlete } \\
\text { Experiencing a } \\
\text { Substantial } \\
\text { Increase in Pain? }\end{array}$ & $\begin{array}{c}\text { Difference in Increase of } \\
\text { Perceived Pain in Race } 2 . \\
\text { (mm, 90\% CI) }\end{array}$ \\
\hline 10 & $9.3,7.5$ to 11 & $\begin{array}{l}\text { Unlikely } \\
(6 / 94 \%)\end{array}$ & $2.1,0.5$ to 3.7 & $\begin{array}{l}\text { Most unlikely } \\
(100 / 0 \%)\end{array}$ & $\begin{array}{c}\text { Most likely, trivial } \\
(7.2,4.9 \text { to } 9.5)\end{array}$ \\
\hline 20 & 22,20 to 24 & $\begin{array}{l}\text { Very likely } \\
(99 / 1 \%)\end{array}$ & $4.2,2.6$ to 5.9 & $\begin{array}{l}\text { Most unlikely } \\
(100 / 0 \%)\end{array}$ & $\begin{array}{l}\text { Most likely, less painful } \\
\quad(18,15 \text { to } 20)\end{array}$ \\
\hline 40 & 43,42 to 45 & $\begin{array}{l}\text { Almost certainly } \\
(100 / 0 \%)\end{array}$ & $8.4,6.8$ to 10 & $\begin{array}{l}\text { Unlikely } \\
(19 / 81 \%)\end{array}$ & $\begin{array}{l}\text { Most likely, less painful } \\
\quad(35,33 \text { to } 37)\end{array}$ \\
\hline 60 & 65,63 to 67 & $\begin{array}{l}\text { Almost certainly } \\
(100 / 0 \%)\end{array}$ & 13,11 to 14 & $\begin{array}{l}\text { Possibly } \\
(54 / 46 \%)\end{array}$ & $\begin{array}{l}\text { Most likely, less painful } \\
\quad(52.5,50.2 \text { to } 54.8)\end{array}$ \\
\hline 80 & 87,85 to 89 & $\begin{array}{l}\text { Almost certainly } \\
(100 / 0 \%)\end{array}$ & 17,15 to 19 & $\begin{array}{l}\text { Possibly } \\
(73 / 27 \%)\end{array}$ & $\begin{array}{l}\text { Most likely, less painful } \\
\quad(70,68 \text { to } 72)\end{array}$ \\
\hline
\end{tabular}

The point at which the increases in perceived pain was likely substantial was $\sim 15$ miles in race 1 and $\sim 100$ miles in race 2 .

Table 4. Increases in perceived hunger over each ultra-marathon run including the likelihood that the athlete was experiencing a substantial increase in hunger. Likelihoods are presented with the qualitative inference and percentage chance the athlete was substantially more hungry, trivial, or less hungry. Differences between are presented as raw change and $90 \%$ confidence interval, with the qualitative inference.

\begin{tabular}{|c|c|c|c|c|c|}
\hline $\begin{array}{l}\text { Miles } \\
(\mathrm{x})\end{array}$ & $\begin{array}{c}\text { Change in Hunger } \\
\text { per } x \text { Miles } \\
(\mathrm{mm}, 90 \% \mathrm{CI})\end{array}$ & $\begin{array}{l}\text { Was the Athlete } \\
\text { Experiencing a } \\
\text { Substantial Increase } \\
\text { in hunger? }\end{array}$ & $\begin{array}{l}\text { Increases in Perceived } \\
\text { Hunger per } x \text { Miles } \\
(\mathrm{mm}, 90 \% \mathrm{CI})\end{array}$ & $\begin{array}{l}\text { Was the Athlete } \\
\text { Experiencing a } \\
\text { Substantial Increase } \\
\text { in Hunger? }\end{array}$ & $\begin{array}{c}\text { Difference in Increase of } \\
\text { Perceived Hunger in } \\
\text { Race } 2 . \\
(\mathrm{mm}, 90 \% \mathrm{CI})\end{array}$ \\
\hline 10 & $2.4,0.3$ to 4.6 & $\begin{array}{l}\text { Most unlikely } \\
(0 / 100 / 0 \%)\end{array}$ & $0.1,-2.1$ to 2.2 & $\begin{array}{l}\text { Most unlikely } \\
(0 / 100 / 0 \%)\end{array}$ & $\begin{array}{l}\text { Most likely, trivial } \\
(2.4,-0.5 \text { to } 5.3)\end{array}$ \\
\hline 20 & $4.9,2.7$ to 7.0 & $\begin{array}{l}\text { Very unlikely } \\
(1 / 99 / 0 \%)\end{array}$ & $0.1,-2.0$ to 2.3 & $\begin{array}{l}\text { Most unlikely } \\
(0 / 100 / 0 \%)\end{array}$ & $\begin{array}{c}\text { Most likely, trivial } \\
(4.8,1.9 \text { to } 7.6)\end{array}$ \\
\hline 40 & $9.7,7.6$ to 12 & $\begin{array}{c}\text { Possibly } \\
(33 / 67 / 0 \%)\end{array}$ & $0.2,-1.9$ to 2.4 & $\begin{array}{l}\text { Very unlikely } \\
(2 / 96 / 2 \%)\end{array}$ & $\begin{array}{l}\text { Likely trivial } \\
(9.5,6.6 \text { to } 12)\end{array}$ \\
\hline 60 & 15,13 to 17 & $\begin{array}{c}\text { Possibly } \\
(63 / 36 / 0 \%)\end{array}$ & $0.4,-1.8$ to 2.5 & $\begin{array}{l}\text { Unlikely } \\
(8 / 86 / 7 \%)\end{array}$ & $\begin{array}{c}\text { Likely, lower } \uparrow \\
\text { hunger }(14,11 \text { to } 17)\end{array}$ \\
\hline 80 & 20,17 to 22 & $\begin{array}{c}\text { Likely } \\
(76 / 23 / 1 \%)\end{array}$ & $0.5,-1.7$ to 2.6 & $\begin{array}{c}\text { Unlikely } \\
(14 / 74 / 12 \%)\end{array}$ & $\begin{array}{c}\text { Most likely, lower } \uparrow \\
\text { hunger }(19,16 \text { to }-22)\end{array}$ \\
\hline
\end{tabular}

The point at which the increase in perceived hunger was likely substantial was $\sim 80$ miles in race 1 .

\section{Discussion}

The current study describes the assessment and progression of physiological and subjective variables in the context of two contrasting ultra-marathon attempts. These data informed the nutrition, and sports science support strategies that were implemented during and between events. Improvements in subjective measures of pain, motivation, freshness and hunger corresponded to performance resulting in race completion, independent of changes in RPE, which was relatively stable over the course of both attempts. Maximum reported values during both attempts were similar for RPE (non-completion: 4; Somewhat Hard, completion: 5; Hard), whereas other subjective measures oscillated throughout the events, suggesting either that these variables were more sensitive to intervention, or that visual analogue scales provide a more discriminate measure of such variables. Change scores in RPE equated to $\sim 0.5$ arbitrary units per 100 miles, hence an alternative scale to the CR-10 [27] is required to detect changes in RPE within this athlete, or over this duration.

No incidence of acute trauma was noted throughout non-completion; as such, the increased pain slope seen in Figure 1 cannot be attributed to an incident, but an inability of the osteoarticular tissue to tolerate periods of sustained running. It is postulated that the Al Andulus trail, completed successfully between the reported attempts served to develop the athlete's tissue and subjective tolerances for ultra-endurance running. This is supported through regression data suggesting that the best 
predictors of ultra-marathon performance are mean weekly running kilometres and training speed [10], and recommendations that runners develop strategies to limit tissue damage throughout training and competition [11].

The progression of subjective measures suggests that the strategies to attenuate or modify the perception of pain throughout ultra-running races may also positively impact upon motivation and freshness, and as such improve performance through a combination of increased running speed, fewer walk breaks, and potentially shorter feeding times. Caffeine may be one such strategy; caffeine has been shown to ameliorate leg pain during moderate intensity exercise $\left(60 \% \mathrm{VO}_{2 \max }\right)$ in a dose dependent fashion [35], and has been consumed throughout a 100mile race in 3 elite ultra-runners at a rate of $0.9 \pm 0.27 \mathrm{mg} \cdot \mathrm{kg}^{-1} \cdot \mathrm{h}^{-1}$ [17]. Timely caffeine consumption may not only alleviate perceptions of pain, but may also improve freshness [36] potentially combatting the circadian challenges of ultra-endurance activity, such as event start time and volume of night time running.

A greater attenuation of hunger as was achieved in race completion, may also be a strategy to indirectly improve freshness and motivation, and may mitigate pain. We observed that hunger was moderately correlated with freshness and motivation, and was largely associated with pain during non-completion (Race 1; Table 2); whereas, during completion when higher nutritional intakes were attained and hunger was perceived to be lower and more stable (Figure 1) correlations between hunger and freshness (Trivial; $0.15,-0.38$ to 0.6 ) and motivation (Trivial; $0.06,-0.45$ to 0.54 ) reduced in magnitude (Race 2; Table 2), with no likely substantial differences in hunger observed during completion (Table 4). This change in hunger, and its ability to ameliorate decreases in freshness and motivation, concomitantly increased the relationship between hunger and pain from large $(0.56,-0.04$ to 0.86$)$ to very large $(0.7,0.3$ to 0.89$)$, suggesting that a well-fed athlete is less likely to report pain, and vice versa, a poorly nourished athlete is more likely to experience pain. The differences in freshness and motivation also suggest that, in this case report, the participant may have differentiated between sensations when hunger was elevated, with freshness, motivation, and pain all perceived discretely and capable of influencing race performance and completion; hence, a negative change in one variable may have produced a further negative cascade between wider measures. Whereas when hunger was lower (completion), pain may have been interpreted as a cumulative integration of sensations of freshness, motivation, and pain.

The higher food and carbohydrate (absolute and relative) consumption achieved during completion supports the notion that trainability of the gut is a contributing factor in successful ultra-endurance exercise performance [16,24]. Events are primarily contested over a fixed distance, and, as such, if an athlete is quicker, the same absolute carbohydrate intake is distributed over a shorter time frame resulting in a higher relative intake. Our data suggest that the athlete managed to improve their tolerance to feeding between attempts, as $\mathrm{CHO}$ intake increased by $\sim 5 \mathrm{~g} \cdot \mathrm{hr}^{-1}$, was tolerated over a longer duration and it formed a larger percentage of nutritional intake (66\% increase). Surprisingly, fewer sports nutrition products were consumed throughout the successful attempt. This is contrary to previous reports [17], which suggest that large $\mathrm{CHO}$ intakes are readily achieved by using such foodstuffs. Instead, the athlete consumed a variety of $\mathrm{CHO}$ sources; preferring fruit at aid stations and rice cakes between stations. This feeding strategy represents current guidance to consume multiple transportable carbohydrates from glucose and fructose sources [23], and is evidenced by the increase across all the constituent sugars between successful and failed attempts. The increase in sucrose consumption from $75 \mathrm{~g}$ to $98 \mathrm{~g}$ during completion, despite using fewer sports nutrition products, may be an artefact of race duration in that more food was consumed and data obtained.

Mechanistically, the higher $\mathrm{CHO}$ intake may have served to combat the decline in running economy and maximal sustainable power likely experienced over the course of the event [12]. A higher $\mathrm{CHO}$ intake would elevate the respiratory quotient, improving efficiency and attenuating the expected increase in fractional utilisation of $\mathrm{VO}_{2 \max }$. This may prove advantageous through technical or hilly sections of ultra-endurance events, where an increase in anaerobic energy contribution may be required, and a reciprocal down-regulation of fat metabolism occurs [37,38]. Adopting a low 
carbohydrate high fat diet is currently in vogue in ultra-endurance sports [37,39]. High rates of fat oxidation $(1.54 \pm 0.18 \mathrm{~g} / \mathrm{min})$ have been observed in trained ultra-distance runners when self-reported habitual dietary changes are implemented over at least one year [39]. A greater percentage fat oxidation would contribute towards sustained energy production in the presence of declining or limited glucose availability, however fat oxidation is not a measure of performance per se. Furthermore, higher fat intakes have been shown to impair higher intensity exercise performance, through a down regulation of $\mathrm{CHO}$ metabolism [38,40,41]. In events that are limited by rates of exogenous feeding, and with our data suggesting an improvement (to the point of completion) with greater $\mathrm{CHO}$ feeding rates, 'fat-adaptation' strategies appear to be impractical and potentially deleterious to the athlete's performance.

The role of protein as a substrate has been suggested to increase with exercise duration [42]. Branched chain amino acids are preferentially oxidised and are shown to increase fat oxidation in times of carbohydrate depletion [43]. Due to the catabolic nature and nutritional requirements of ultra-endurance running, branched chain amino acid consumption may attenuate some of the deleterious effects of event participation [43]. Although protein intake increased between events by $\sim 15 \%\left(0.3 \mathrm{~g} \cdot \mathrm{kg}^{-1}\right)$, the difference in protein consumption between attempts is unlikely to have promoted anti-catabolic or oxidative responses because of the concomitant increase in exogenous $\mathrm{CHO}$ provision [42]. The extra protein may however have provided a satiating effect i.e., a reduction in hunger (Figure 2). 

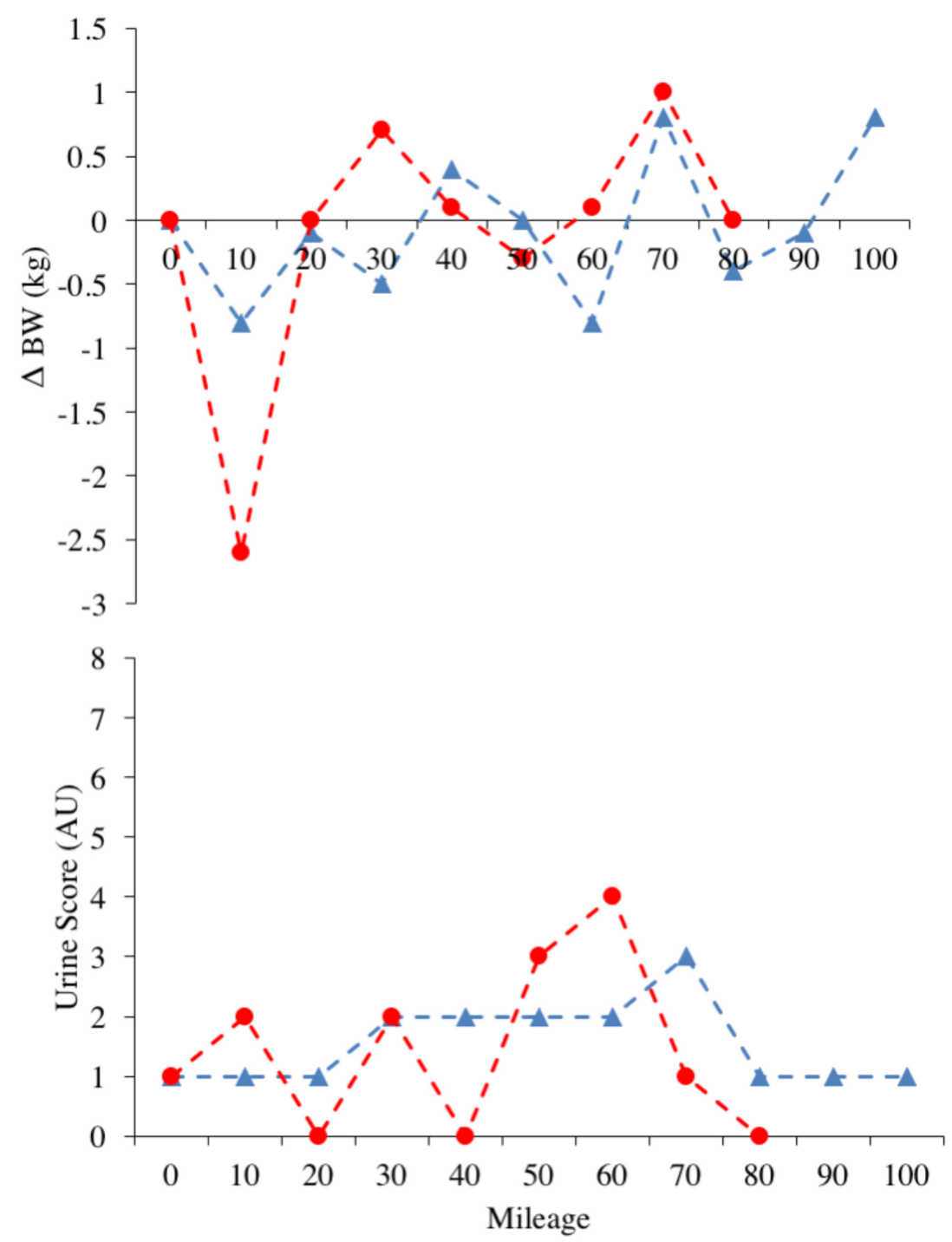

Figure 2. Panels represent the individual data points for race 1 (red circles) and race 2 (blue triangles), for Urine Score and $\Delta \mathrm{BW}$.

Hydration needs, as assessed through $\Delta \mathrm{BW}$ and Urine Score data, were well managed across both events. It is acknowledged that these are indirect measures of hydration, and that both measures are influenced by feeding and substrate usage. However, they present timely and instantaneous methods of obtaining data that can inform strategies in a 'live' context [25] and thy have recently been shown to be valid up to $-2 \% \Delta \mathrm{BW}$ [44]. Our data suggest that within temperate conditions ad libitum drinking can sufficiently maintain indirect hydration measures during ultra-endurance activity of $\sim 24 \mathrm{~h}$ in duration. Ad-libitum drinking is favoured throughout ultra-endurance events, and these recommendations are supported by high reported fluid and sodium $[8,15]$ intakes during ultra-marathon running [45] and low incidence of hyponatraemia [19]. Special consideration should be given to individual athletes' sweat responses and sodium loss through participation in ultra-endurance activity, as very high inter-individual variability in sweat and sodium loss, have been reported [45]. Start time of event may be important in determining these outcomes, as an earlier start time increases the volume of running completed before peak day-time temperatures, serving to decrease sweat rate, as evidenced by a more stable $\Delta$ BW (completion start time 6:00 a.m.) and an improved mean Urine Score (non-completion: 4, completion: 3 ).

Event start time presents a potentially meaningful consideration for future research and support delivery, especially when researchers conduct multiple observations on an athlete(s). Our data suggest 
differing feeding strategies (and performance) between events of differing start times (10:00 a.m. non-completion; 6:00 a.m. completion). We propose that 'rate of peak feeding' i.e., the time at which $\mathrm{CHO}$ consumption is highest throughout the event, may be susceptible to either circadian (event start time), duration (time since start), or environmental (altitude, temperature) influences, as all might be drivers of appetite and or exercise performance [46-50]. Exploration into rates of peak feeding may allow for further individualisation and validation of $\mathrm{CHO}$ consumption guidelines [22] in ultra-endurance competition, providing scope for more flexible feeding strategies, whilst still meeting energetic demands.

\section{Conclusions}

Pain appears to be a key modulator of ultra-endurance running performance, with improvements in perceptions of pain affecting the sensations of freshness and motivation independent of exercise intensity (RPE). Strategies to modify pain in ultra-endurance athletes might improve performance, although we cannot suggest with certainty whether this is an acquired response (competition/training) or one that is directly mediated by intervention e.g., caffeine. In a moderately trained ultra-endurance athlete, a small improvement in the ability to tolerate $\mathrm{CHO}$ feeding resulted in improved performance. Tolerance to $\mathrm{CHO}$ feeding is a trainable determinant of ultra-endurance activity with higher rates of $\mathrm{CHO}$ positively associated with performance, and training status. Future research should investigate rates of peak feeding throughout similar events, with the goal of ascertaining whether competition nutrition strategies can be tailored specifically towards individual tolerance, within the context of current recommendations, event conditions, and logistics.

Author Contributions: Conceptualization, R.B., B.B., N.B. and J.S.; Methodology, R.B., B.B., N.B., C.H. and J.S.; Formal Analysis, R.B, B.B. and M.W.; Investigation, R.B., B.B. and A.B.; Resources, R.B. and N.B.; Data Curation, R.B., B.B., N.B. and M.W.; Statistical Analyses, M.W.; Writing-Original Draft Preparation, R.B., B.B., A.B., N.B. and J.S.; Writing-Review \& Editing, R.B., B.B., A.B., N.B., M.W. and J.S.

Funding: This research received no external funding.

Acknowledgments: The authors would like to thank the participant for their cooperation and receptiveness to monitoring and support throughout the two attempts, and the surrounding time period. We would also like to extend our thanks to the race organizers, other participants and support crews for their interest in our efforts.

Conflicts of Interest: The authors declare no conflict of interest.

\section{References}

1. IAAF Ultra-Running. Available online: http://www.iaaf.org/disciplines/ultra-running/ultra-running (accessed on 9 August 2018).

2. Knoth, C.; Knechtle, B.; Rüst, C.A.; Rosemann, T.; Lepers, R. Participation and performance trends in multistage ultramarathons-the "Marathon des Sables" 2003-2012. Extrem. Physiol. Med. 2012, 1, 13. [CrossRef] [PubMed]

3. Cona, G.; Cavazzana, A.; Paoli, A.; Marcolin, G.; Grainer, A.; Bisiacchi, P.S. It's a Matter of Mind! Cognitive Functioning Predicts the Athletic Performance in Ultra-Marathon Runners. PLoS ONE 2015, 10, e0132943. [CrossRef] [PubMed]

4. Millet, G.P.; Millet, G.Y. Ultramarathon is an outstanding model for the study of adaptive responses to extreme load and stress. BMC Med. 2012, 10. [CrossRef] [PubMed]

5. Martin, K.; Staiano, W.; Menaspà, P.; Hennessey, T.; Marcora, S.; Keegan, R.; Thompson, K.G.; Martin, D.; Halson, S.; Rattray, B. Superior Inhibitory Control and Resistance to Mental Fatigue in Professional Road Cyclists. PLoS ONE 2016, 11, e0159907. [CrossRef] [PubMed]

6. Freund, W.; Weber, F.; Billich, C.; Birklein, F.; Breimhorst, M.; Schuetz, U.H. Ultra-Marathon Runners Are Different: Investigations into Pain Tolerance and Personality Traits of Participants of the TransEurope FootRace 2009. Pain Pract. 2013, 13, 524-532. [CrossRef] [PubMed]

7. Millet, G.Y. Can Neuromuscular Fatigue Explain Running Strategies and Performance in Ultra-Marathons? Sports Med. 2011, 41, 489-506. [CrossRef] [PubMed]

8. Glace, B.; Murphy, C.; McHugh, M. Food and fluid intake and disturbances in gastrointestinal and mental function during an ultramarathon. Int. J. Sport Nutr. Exerc. Metab. 2002, 12, 414-427. [CrossRef] [PubMed] 
9. Glace, B.W.; Murphy, C.A.; McHugh, M.P. Food Intake and Electrolyte Status of Ultramarathoners Competing in Extreme Heat. J. Am. Coll. Nutr. 2013, 21, 553-559. [CrossRef]

10. Knechtle, B.; Knechtle, P.; Rosemann, T.; Senn, O. What is associated with race performance in male 100-km ultra-marathoners-anthropometry, training or marathon best time? J. Sports Sci. 2011, 29, 571-577. [CrossRef] [PubMed]

11. Millet, G.Y.; Hoffman, M.D.; Morin, J.B. Sacrificing economy to improve running performance-a reality in the ultramarathon? J. Appl. Physiol. 2012, 113, 507-509. [CrossRef] [PubMed]

12. Lazzer, S.; Salvadego, D.; Rejc, E.; Buglione, A.; Antonutto, G.; di Prampero, P.E. The energetics of ultra-endurance running. Eur. J. Appl. Physiol. 2012, 112, 1709-1715. [CrossRef] [PubMed]

13. Freund, W.; Weber, F.; Billich, C.; Schuetz, U.H. The foot in multistage ultra-marathon runners: Experience in a cohort study of 22 participants of the Trans Europe Footrace Project with mobile MRI. BMJ Open 2012, 2, e001118. [CrossRef] [PubMed]

14. Jagim, A.; Levers, K.; Galvan, E.; Joubert, D.; Rasmussen, C.; Greenwood, M.; Kreider, R.B. Effects of an Ultra-Endurance Event on Body Composition, Exercise Performance and Markers of Clinical Health: A Case Study. Bioenergetics 2014, 3. [CrossRef]

15. Costa, R.J.S.; Gill, S.K.; Hankey, J.; Wright, A.; Marczak, S. Perturbed energy balance and hydration status in ultra-endurance runners during a $24 \mathrm{~h}$ ultra-marathon. Br. J. Nutr. 2014, 112, 428-437. [CrossRef] [PubMed]

16. Costa, R.J.S.; Snipe, R.; Camões-Costa, V.; Scheer, V.; Murray, A. The Impact of Gastrointestinal Symptoms and Dermatological Injuries on Nutritional Intake and Hydration Status During Ultramarathon Events. Sports Med. Open 2016, 2. [CrossRef] [PubMed]

17. Stellingwerff, T. Competition Nutrition Practices of Elite Ultramarathon Runners. Int. J. Sport Nutr. Exerc. Metab. 2016, 26, 93-99. [CrossRef] [PubMed]

18. Noakes, T.D. Is Drinking to Thirst Optimum? Ann. Nutr. Metab. 2010, 57, 9-17. [CrossRef] [PubMed]

19. Hew-Butler, T.; Rosner, M.H.; Fowkes-Godek, S.; Dugas, J.P.; Hoffman, M.D.; Lewis, D.P.; Maughan, R.J.; Miller, K.C.; Montain, S.J.; Rehrer, N.J.; et al. Statement of the Third International Exercise-Associated Hyponatremia Consensus Development Conference, Carlsbad, California, 2015. Clin. J. Sports Med. 2015, 25, 303-320. [CrossRef] [PubMed]

20. Burke, L.M. Feeding ultra-endurance athletes: An interview with Dr. Helen O'Connor and Gregory Cox. Int. J. Sport Nutr. Exerc. Metab. 2002, 12, 490-494. [CrossRef]

21. Wardenaar, F.C.; Dijkhuizen, R.; Ceelen, I.J.M.; Jonk, E.; de Vries, J.H.M.; Witkamp, R.F.; Mensink, M. Nutrient Intake by Ultramarathon Runners: Can They Meet Recommendations? Int. J. Sport Nutr. Exerc. Metab. 2015, 25, 375-386. [CrossRef] [PubMed]

22. Jeukendrup, A. A Step Towards Personalized Sports Nutrition: Carbohydrate Intake During Exercise. Sports Med. 2014, 44, 25-33. [CrossRef] [PubMed]

23. Stellingwerff, T.; Cox, G.R. Systematic review: Carbohydrate supplementation on exercise performance or capacity of varying durations. Appl. Physiol. Nutr. Metab. 2014, 39, 998-1011. [CrossRef] [PubMed]

24. De Oliveira, E.P.; Burini, R.C.; Jeukendrup, A. Gastrointestinal Complaints During Exercise: Prevalence, Etiology, and Nutritional Recommendations. Sports Med. 2014, 44, 79-85. [CrossRef] [PubMed]

25. Armstrong, L.E. Assessing Hydration Status: The Elusive Gold Standard. J. Am. Coll. Nutr. 2013, 26, 575S-584S. [CrossRef]

26. Pageaux, B. Perception of effort in Exercise Science: Definition, measurement and perspectives. Eur. J. Sport Sci. 2016, 16, 885-894. [CrossRef] [PubMed]

27. Borg, G. Borg's Perceived Exertion and Pain Scales; Human Kinetics: Champaign, IL, USA, 1998.

28. Hopkins, W.G.; Marshall, S.W.; Batterham, A.M.; Hanin, J. Progressive Statistics for Studies in Sports Medicine and Exercise Science. Med. Sci. Sport Exerc. 2009, 41, 3-13. [CrossRef] [PubMed]

29. Hopkins, W.G. A Spreadsheet for Monitoring an Individual's Changes and Trend. Sportscience 2017, 21, 5-9.

30. Hopkins, W.G. A Spreadsheet for Combining Outcomes from Several Subject Groups. Sport Sci. 2006, 10, 51-53.

31. Batterham, A.M.; Hopkins, W.G. Making meaningful inferences about magnitudes. Int. J. Sports Physiol. Perform. 2006, 1, 50-57. [CrossRef] [PubMed]

32. Wallace, L.K.; Slattery, K.M.; Impellizzeri, F.M.; Coutts, A.J. Establishing the criterion validity and reliability of common methods for quantifying training load. J. Strength Cond. Res. 2014, 28, 2330-2337. [CrossRef] [PubMed]

33. Kelly, A.M. The minimum clinically significant difference in visual analogue scale pain score does not differ with severity of pain. Emerg. Med. J. 2001, 18, 18-205. [CrossRef] 
34. Bijur, P.E.; Silver, W.; Gallagher, E.J. Reliability of the visual analog scale for measurement of acute pain. Acad. Emerg. Med. 2001, 8, 1153-1157. [CrossRef] [PubMed]

35. O'Connor, P.J.; Motl, R.W.; Broglio, S.P.; Ely, M.R. Dose-dependent effect of caffeine on reducing leg muscle pain during cycling exercise is unrelated to systolic blood pressure. Pain 2004, 109, 291-298. [CrossRef] [PubMed]

36. Goldstein, A.; Kaizer, S.; Warren, R. Psychotropic effects of caffeine in man. II. Alertness, psychomotor coordination, and mood. J. Pharmacol. Exp. Ther. 1965, 150, 146-151. [PubMed]

37. Burke, L.M. Re-Examining High-Fat Diets for Sports Performance: Did We Call the "Nail in the Coffin" Too Soon? Sports Med. 2015, 45, 33-49. [CrossRef] [PubMed]

38. Spriet, L.L. New Insights into the Interaction of Carbohydrate and Fat Metabolism During Exercise. Sports Med. 2014, 44, 87-96. [CrossRef] [PubMed]

39. Volek, J.S.; Freidenreich, D.J.; Saenz, C.; Kunces, L.J. Metabolic characteristics of keto-adapted ultra-endurance runners. Metabolism 2016, 65, 100-110. [CrossRef] [PubMed]

40. Stellingwerff, T. Decreased PDH activation and glycogenolysis during exercise following fat adaptation with carbohydrate restoration. Am. J. Physiol. Endocrinol. Metab. 2005, 290, E380-E388. [CrossRef] [PubMed]

41. Yeo, W.K.; Carey, A.L.; Burke, L.; Spriet, L.L.; Hawley, J.A. Fat adaptation in well-trained athletes: Effects on cell metabolism. Appl. Physiol. Nutr. Metab. 2011, 36, 12-22. [CrossRef] [PubMed]

42. Gibala, M.J. Protein metabolism and endurance exercise. Sports Med. 2007, 37, 337-340. [CrossRef] [PubMed]

43. Gualano, A.B.; Bozza, T.; Lopes, D. Branched-chain amino acids supplementation enhances exercise capacity and lipid oxidation during endurance exercise after muscle glycogen depletion. J. Sports Med. Phys. Fit. 2011, $51,82-88$.

44. McKenzie, A.L.; Munoz, C.X.; Armstrong, L.E. Accuracy of Urine Color to Detect Equal to or Greater Than 2\% Body Mass Loss in Men. J. Athl. Train 2015, 50, 1306-1309. [CrossRef] [PubMed]

45. Hoffman, M.D.; Stellingwerff, T.; Costa, R.J.S. Considerations for ultra-endurance activities: Part 2-hydration. Res. Sports Med. 2018, 00, 1-13. [CrossRef] [PubMed]

46. Blundell, J.E.; Gibbons, C.; Caudwell, P.; Finlayson, G.; Hopkins, M. Appetite Control and Energy Balance: Impact of Exercise. Obes. Rev. 2015, 16, 67-76. [CrossRef] [PubMed]

47. Wasse, L.K.; Sunderland, C.; King, J.A.; Batterham, R.L.; Stensel, D.J. Influence of rest and exercise at a simulated altitude of $4000 \mathrm{~m}$ on appetite, energy intake, and plasma concentrations of acylated ghrelin and peptide YY. J. Appl. Physiol. 2012, 112, 552-559. [CrossRef] [PubMed]

48. Kojima, C.; Sasaki, H.; Tsuchiya, Y.; Goto, K. The influence of environmental temperature on appetite-related hormonal responses. J. Physiol. Anthropol. 2015, 34. [CrossRef] [PubMed]

49. Wolff, G.; Esser, K.A. Scheduled exercise phase shifts the circadian clock in skeletal muscle. Med. Sci. Sport Exerc. 2012, 44, 1663-1670. [CrossRef] [PubMed]

50. Gonnissen, H.K.J.; Rutters, F.; Mazuy, C.; Martens, E.A.P.; Adam, T.C.; Westerterp-Plantenga, M.S. Effect of a phase advance and phase delay of the 24-h cycle on energy metabolism, appetite, and related hormones. Am J. Clin. Nutr. 2012, 96, 689-697. [CrossRef] [PubMed]

(C) 2018 by the authors. Licensee MDPI, Basel, Switzerland. This article is an open access article distributed under the terms and conditions of the Creative Commons Attribution (CC BY) license (http://creativecommons.org/licenses/by/4.0/). 